Available online at : http://journal.unj.ac.id/unj/index.php/gjik

Gladi Jurnal Ilmu Keolahragaan 09 (01) 2018, 24 - 34

Permalink/DOI: https://doi.org/10.21009/GJIK.091.02

\title{
OPTIMALISASI PEMANFAATAN MINERAL FOSFOR DALAM MEMBENTUK KESEHATAN FISIK ANAK USIA DINI MELALUI REEDUKASI KELUARGA
}

\author{
Sandey Tantra Paramitha ${ }^{1}$ \\ ${ }^{1}$ Departemen Pendidikan Kesehatan dan Rekreasi Program Studi Ilmu Keolahragaan, \\ Jl. Dr. Setiabudhi No. 229 Bandung Kode Pos 40154 \\ *Corresponding Author. Email: sandeytantra18@upi.edu
}

Received: 15 February 2018; Revision: 20 February 2018; Accepted:01 March 2018

\begin{abstract}
Abstrak : Perkembangan kesehatan fisik anak usia dini sangat ditentukan oleh kadar fosfor yang terdapat dalam tubuh, karena menjadi unsur terbesar kedua setelah kalsium dalam tubuh manusia, permasalahan yang menjadi kendala dalam mengembangkan pengetahuan keluarga mengenai pentingnya kandungan fosfor dalam perkembangan tubuh anak usia dini yaitu kondisi lingkungan yang kurang mendukung serta tidak ada dukungan yang masif dari kementerian kesehatan mengenai pentingnya fosfor bagi pertumbuhan anak usia dini. Penelitian ini menggunakan metode deskriptif yang bertujuan untuk mendeskripsikan, menggambarkan dan menganalisis kejadian dilapangan, teknik pengumpulan data menggunakan wawancara, observasi dan dokumentasi, serta menggunakan teknik analisis data penyajian data, reduksi data serta penarikan kesimpulan. Hasil yang diperoleh menunjukan bahwa masyaratakat kurang memiliki pengetahuan mengenai pentingnya fosfor bagi pertumbuhan anak usia dini, maka perlu adanya pengembangan pengetahuan masyarakat mengenai pentingnya fosfor bagi pertumbuhan anak usia dini, hal tersebut dikarenakan kelebihan maupun kekurangan fosfor akan berdampak tidak bak bagi tubuh.
\end{abstract}

Kata kunci: Anak Usia Dini; Fosfor; Kesehatan Fisik

\begin{abstract}
The development of early childhood physical health largely determined by levels of phosphorus contained in the body, due to be the second largest item after the calcium in the human body, problems become obstacles in developing family knowledge about the importance of the content of phosphorus in the development of early childhood body i.e. environmental conditions is lacking support and there is no massive support from the Ministry of Health important about phosphorus for the growth of early childhood. This research uses descriptive method which aims to describe, illustrate and analyze events in field data collection techniques, using interviews, observation and documentation, as well as using the techniques of data analysis the presentation of data, data reduction and withdrawal of the conclusion. The results obtained show that the society have less knowledge about the importance of phosphorus for early childhood growth, hence the need for the development of the knowledge society on the importance of phosphorous for growth in early childhood, it due to the excess or deficiency of phosphorus will not impact the tub for the body.
\end{abstract}

Keywords: Early Childhood; Phosphorus; Physical Health 


\section{PENDAHULUAN}

Pentingnya mineral fosfor sebagai zat gizi mikro menempati urutan kedua setelah kalsium dalam total kandungan tubuh (Siswanto; Budisetyawati, 2013). Fungsi utama fosfor sebagai pemberi energi dan kekuatan untuk metabolisme lemak dan pati, sebagai penunjang kesehatan gigi dan gusi, untuk sintesis DNA serta penyerapan dan pemakaian kalsium (Emilia, 2009). Hal ini menandakan bahwa fungsi fosfor sangat penting dalam membentuk kesehatan fisik manusia, terutama anak usia dini yang sedang dalam masa pertumbuhan fisik.

Fosfor merupakan zat penting dari semua jaringan tubuh, mengembangkan fungsi otot dan sel-sel darah merah (Moniaga \& Pangemanan, 2013). Maka dapat diketahui bahwa fosfor erat kaitannya dengan metabolisme tubuh yang berguna dalam meningkatkan daya tahan tubuh. Pentingnya fosfor untuk anak usia dini ialah sebagai unsur penting dalam mengoptimalkan pertumbuhan fisik, sehingga kekurangan fosfor dalam tubuh anak usia dini akan berakibatkan pada tidak optimalnya pertumbuhan fisik (Kusbiantoro, 2015).

Manfaat Fosfor terbesar bagi kesehatan tubuh yaitu untuk membantu proses pembentukan tulang dan gigi yang sehat, selain itu fosfor juga berfungsi untuk meningkatkan kinerja proses pencernaan makanan serta membantu pengaturan proses pembuangan sisa metabolisme dan zat-zat yang tidak berguna bagi tubuh (Kuniano, 2015). Sehingga akan membuat efektivitas dalam kinerja tubuh lebih optimal.

Pada aspek lain, fosfor juga memiliki peran yang sangat besar dalam pembentukan protein, menjaga keseimbangan produksi dan fungsi hormon, serta meningkatkan proses pemisahan suatu zat yang dibutuhkan untuk menghasilkan energi. Fosfor juga berfungsi dalam mengoptimalkan reaksi kimia dalam tubuh serta membantu tubuh memanfaatkan nutrisi secara tepat (Ani, 2011).

Bahan pangan yang mengandung fosfor terdapat dalam jenis pangan organik dan anorganik (Suarni \& Muh. Yasin, 2016), sebagian besar fosfor diserap tubuh dalam bentuk anorganik, khususnya di bagian atas duodenum yang bersifat kurang alkalis sebanyak $70 \%$ yang akan diserap. Kandungan fosfor dalam makanan banyak terdapat dalam makanan yang tinggi protein, seperti ikan, ayam, daging, telur, kacang-kacangan, biji-bijian, dan serelia atau gandum (Rahayu \& K.S. Sugiarto, 2015).

Source of Protein-rich foods also is usually a food source of phosphorus (Satish Kumar et al., 2013). Selain itu, makanan dengan kandungan kalsium yang tinggi 
biasanya juga mengandung fosfor dalam jumlah tinggi (Syarifah, 2015). Dalam penelitian terdahulu menunjukkan bahwa makanan sumber fosfor yang berasal dari daging akan lebih mudah diserap oleh tubuh, bila dibandingkan dengan makanan sumber fosfor yang berasal dari tumbuhan (Komariyah, 2011).

Daily requirement of phosphorus is different for every person, but in general human need 1,000 milligrams of phosphorus for every day (Yuan, Pratt, \& Batstone, 2012). Selain itu, biji labu dan labu kuning merupakan salah satu makanan sumber fosfor yang tinggi dari golongan biji-bijian. Dalam setiap 28 gram biji labu dan labu kuning mengandung 345 miligram fosfor (Ariati \& Ratnayani, 2017).

Keju yang terbuat dari susu domba, susu kambing dan susu sapi dalam setiap 28 gram keju, bisa memenuhi kebutuhan fosfor sebesar $28 \%$. Untuk jenis keju yang mudah ditemui di pasaran, keju adalah yang tertinggi persentasenya dalam memenuhi kebutuhan Fosfor sebanyak 23\% (Mardiani, Sumarmono, \& Setyawardani, 2013).

Ikan tuna dan ikan mackerel memiliki jumlah fosfor yang cukup tinggi, masing-masing memiliki $28 \%$ dan $27 \%$ fosfor untuk setiap 85 gram berat dan sudah dalam kondisi dimasak. Ikan lainnya semacam tongkol, kembung, dan jenis ikan cakalang juga termasuk yang memiliki kandungan fosfor tinggi (Musfiroh, Susanti, \& Sukmawardani, 2016). Hal ini menandakan konsumsi ikan setiap hari dapat memenuhi kandungan fosfor anak usia dini.

Bukan hanya pada jenis ikan dan sayuran, kandungan fosfor juga terdapat pada daging sapi, karena mengandung 264 miligram dan 243 miligram fosfor atau memenuhi setidaknya $26 \%$ dan $24 \%$ fosfor (Rahayu \& K.S. Sugiarto, 2015). Hal tersebut menandakan bahwa daging sapi sangat penting dalam pembentukan kesehatan fisik anak usia dini.

Produk olahan juga memiliki fosfor yang sangat tinggi, karena dalam setiap satu yogurt setara dengan berat 245 gram, yoghurt juga mengandung sedikitnya 385 miligram fosfor atau memenuhi setidaknya $38 \%$ kebutuhan fosfor setiap hari (Rahayu \& K.S. Sugiarto, 2015).

The mineral phosphorus utilization in shaping the physical health of children is very important in the process of growth, due to the lack of phosphorus will result in the absorption of calcium is not optimal (Hill \& Fanta, 2008). Selain itu, kurangnya fosfor dalam anak usia dini akan berakibat pada kurang energi, pertahanan tubuh dan pola otak. Hal ini menandakan bahwa fosfor sangat menunjang terhadap pertumbuhan anak usia dini. 
Due to an excess of Phosphorus will bring up complaints of pain in the bone bone health will suffer disturbance when you prioritize the role of phosphorus to the body by consuming foods containing large amounts of phosphorus (Cupisti \& Kalantar-Zadeh, 2013). Selain itu gangguan pada organ ginjal sebagai kesadaran atas pentingnya peran fosfor bagi tubuh, akan terasa jika sudah berada pada usia lansia.

High levels of phosphorus in the body will produce a phosphate ion and binds to calcium in the body so that in the long run will lead to a seizure in someone (López-Arredondo, Leyva-González, González-Morales, López-Bucio, \& Herrera-Estrella, 2014). Kejang yang diakibatkan oleh berkurangnya fosfor sangat tidak baik dari pertumbuhan fisik anak usia dini, karena akan ada sel-sel dalam tubuh yang tidak berfungsi optimal.

Kesadaran masyarakat akan hidup sehat masih kurang, hal tersebut dapat dilihat dari kesadaran, kemauan dan kemampuan hidup sehat harus dimiliki oleh seluruh lapisan masyarakat. Akan tetapi, derajat kesehatan masyarakat Indonesia telah banyak mengalami peningkatan, walaupun kemajuan tersebut belum dirasakan secara luas oleh masyarakat.

Kesadaran hidup sehat yang kurang dari masyarakat Indonesia disebabkan karena sampai saat ini pembangunan kesehatan masih diharapkan dengan berbagai masalah, seperti kondisi lingkungan yang belum kondusif, terbatasnya ketersediaan dan akses air bersih, rendahnya akses sanitasi, tingginya polusi udara akibat kebakaran hutan dan polusi asap kendaraan dan lain-lain (Widayatun \& Fatoni, 2013). Selain itu, budaya hidup sehat yang rendah, cuci tangan, lingkungan yang kotor, limbah dan sanitasi yang buruk mengakibatkan sulit menanamkan kesadaran hidup sehat bagi masyarakat.

Permasalahan saat ini mengenai pemanfaatan fosfor yaitu masyarakat kurang mengetahui pentingnya fosfor dalam pertumbuhan anak usia dini, padahal pengetahuan masyarakat sangat penting dalam pertumbuhan anak. Hal ini mengakibatkan pertumbuhan anak di Indonesia belum optimal dibandingkan dengan anak usia dini di negara maju.

Optimalisasi untuk memberikan kesadaran kepada masyarakat akan pentingnya pemanfaatan fosfor dapat dilakukan jika terdapat korelasi antara pemerintah, sekolah dan keluarga dalam mengembangkan hidup sehat. Kegiatan tersebut harus berjalan secara berkesinambungan dan terus menerus dalam menerapkan hidup sehat bagi masyarakat. 
Urgensi pengetahuan masyarakat mengenai pemanfaatan fosfor pada anak usia dini akan membuat anak-anak Indonesia mempunyai kesehatan fisik yang baik, karena fosfor sangat penting dalam penyerapan kalsium, meningkatkan energi dan pertumbuhan gigi (Nasution, 2016). Hal ini akan menunjang anak usia dini dalam menjalankan aktivitas sehari-hari.

Tujuan dari penelitian ini yaitu untuk dapat mendeskripsikan permasalahan pemanfaatan fosfor bagi anak usia dini, serta untuk ditemukannya strategi dalam mengoptimalkan pemanfaatan fosfor dalam membentuk kesehatan fisik anak usia dini.

\section{METODE}

Penelitian ini menggunakan pendekatan kualitatif dengan metode deskriptif yang bertujuan untuk researching a group of humans, social circumstances, the system of thought or reviewing an event (Jewitt, 2013). Studi deskriptif bertujuan untuk mendeskripsikan, menggambarkan secara sistematis, keadaan faktual dan akurat tentang fakta-fakta yang terjadi dalam kehidupan sosial, sifat-sifat dan hubungan setiap fenomena-fenomena yang diteliti (Rosmiati, 2014).

Subjek dari penelitian ini terdiri dari kalangan akademisi yaitu dosen olahraga, praktisi dalam bidang ahli gizi serta keluarga yang memiliki anak usia dini.
Tempat penelitian ini berada di Kabupaten Bandung Barat, Kecamatan Lembang, pemilihan tempat tersebut dikarenakan Kecamatan Lembang memiliki produksi pangan yang memiliki kandungan fosfor.

Teknik pengambilan data dalam penelitian ini menggunakan wawancara, observasi dan dokumentasi yang dilakukan selama enam bulan untuk mengambil data. Teknik analisis data dalam penelitian ini menggunakan reduksi data, penyajian data dan penarikan kesimpulan yang dilakukan secara sistematis agar hasil yang didapat sesuai dengan keadaan di lapangan.

\section{HASIL DAN PEMBAHASAN}

Berdasarkan hasil penelitian yang diperoleh Peneliti, menunjukkan bahwa kesadaran masyarakat mengenai manfaat fosfor dalam pertumbuhan anak usia ini masih minim, dalam memberikan nilai gizi pangan masih terpengaruh oleh tradisi masyarakat. Hal tersebut memiliki dampak positif maupun negatif, dampak positif yaitu tradisi masyarakat di Lembang cukup baik dalam pemenuhan gizi anak usia dini dikarenakan terdapat produksi olahan makanan yang memiliki kandungan fosfor yang banyak. Sedangkan dampak negatif yaitu masyarakat tidak mengetahui jumlah fosfor yang seimbang untuk anak usia dini, sehingga mengakibatkan jumlah kandungan fosfor yang tidak seimbang. 
A. Optimalisasi Fosfor bagi Pertumbuhan Anak Usia Dini

$$
\text { Optimalisasi fosfor dalam }
$$

meningkatkan kesehatan fisik anak usia dini haruslah seimbang atau sesuai dengan kebutuhan gizi, karena konsep empat sehat lima sempurna sudah tidak dipakai oleh kalangan akademisi maupun praktisi.

Tabel 1.

Kebutuhan Fosfor Berdasarkan Usia

\begin{tabular}{|l|l|l|}
\hline Kalangan & \multicolumn{1}{|c|}{ Usia } & \multicolumn{1}{|c|}{$\begin{array}{c}\text { Kebutuhan } \\
\text { Fosfor }\end{array}$} \\
\hline Bayi & 0-6 Bulan & $100 \mathrm{mg}$ \\
\hline Bayi & 7-12 Bulan & $275 \mathrm{mg}$ \\
\hline Anak & 1-3 Tahun & $460 \mathrm{mg}$ \\
\hline Anak & 4-8 Tahun & $500 \mathrm{mg}$ \\
\hline Anak & 9-12 Tahun & $900-1100 \mathrm{mg}$ \\
\hline Remaja & 13-19 Tahun & $1250 \mathrm{mg}$ \\
\hline Dewasa & $\begin{array}{l}\text { 19 Tahun } \\
\text { Keatas }\end{array}$ & $700 \mathrm{mg}$ \\
\hline
\end{tabular}

Sumber: (Gunardi et al., 2017)

Berdasarkan tabel tersebut,

kebutuhan fosfor anak usia dini yaitu 460 miligram yang harus diserap tubuh setiap harinya. Keseimbangan zat fosfor dalam tubuh dapat mengoptimalkan pertumbuhan fisik anak usia dini, akan tetapi jika berlebihan akan mengakibatkan sakit pada tulang karena the levels of phosphorus in the body is very high it will interfere with the process of bone growth and ultimately, one's physical growth will be constrained (Zhao et al., 2016). Tentu hal tersebut tidak baik untuk anak usia dini karena usia tersebut merupakan tahap awal perkembangan fisik manusia.
Mengonsumsi makanan yang mengandung fosfor terlalu banyak, akan mengakibatkan sakit pada ginjal karena akan terjadi pengendapan fosfor di bagian ginjal. Permasalahan yang demikian akan mengganggu kesehatan fisik anak usia dini dan hal tersebut sangat berbahaya bagi tahap perkembangan anak.

Kadar fosfor yang kurang bagi tubuh juga akan berbahaya bagi perkembangan kesehatan fisik, karena akan mengakibatkan anorexia yang bisa dilihat dari his behaviour which often choosing their food, eat late, weakened muscles and quickly tired of (de Tavernier, 2012). Kebanyakan kekurangan fosfor anak usia dini dialami oleh keluarga yang tidak mampu secara ekonomi untuk membeli makanan yang memenuhi kadar fosfor.

Berbagai masalah kesehatan fisik dikarenakan kelebihan ataupun kekurangan fosfor dalam tubuh manusia tidak sebanyak manfaat yang diperoleh tubuh jika pemanfaatan kadar fosfor yang seimbang. Sehingga, optimalisasi fosfor dalam tubuh sangat tergantung dari keseimbangan kadar fosfor yang diserap oleh tubuh.

Optimalisasi fosfor dalam tubuh sangat berpengaruh pada pertumbuhan tulang dan gigi, karena fosfor akan lebih cepat terserap dengan kalsium sehingga sangat penting dalam pembentukan, pertumbuhan, dan pemeliharaan struktur 
tulang yang kuat. Faktor tulang yang kuat merupakan unsur penting dalam menjalani kehidupan sehari-hari, terutama anak usia dini yang sedang dalam masa pertumbuhan fisik.

Pemanfaatan fosfor yang seimbang sangat penting bagi proses pencernaan, karena fosfor dapat menstimulasi pencernaan dalam meningkatkan daya serap terhadap vitamin dan mineral. Efektivitas yang dihasilkan oleh fosfor dalam proses pencernaan sangat berguna untuk mengatur sirkulasi pencernaan dalam tubuh, sehingga dapat menghasilkan energi yang seimbang dalam tubuh.

Phosphorus has a significant role in maintaining the health of the kidneys, by ensuring the discharge of waste through the kidneys with the intermediary process of formation urinasi and expenditure excretion (Ma et al., 2014). Fungsi fosfor tersebut penting untuk menghilangkan masalah pembuangan zat sisa pada tubuh anak usia dini, karena permasalahan kesulitan dalam membuang zat sisa sering dialami oleh anak usia dini.

Perkembangan otak anak usia dini cukup dipengaruhi oleh fosfor yang terdapat dalam tubuh, karena phosphorus is an essential mineral that is also found in the cells of the brain and the tissues around the brain of man (Cardoso, Brites, \& Brito, 2010). Hal tersebut menandakan bahwa fungsi fosfor sangat diperlukan dalam pembentukan otak pada anak usia dini, terutama dalam meningkatkan kecerdasan.

Pemanfaatan fosfor yang seimbang juga akan mengefektifkan penggunaan sistem organ, karena phosphorus helps the flow and use of nutrients with organ systems efficiently to maintain the optimum function of each organ of the body (Lee \& Sung, 2013).

Semua manfaat fosfor yang diterima oleh tubuh harus diimbangi dengan gerak fisik anak usia dini dalam aktivitas seharihari, sehingga akan membentuk kesehatan fisik anak usia dini secara optimal.

\section{B. Strategi Meningkatkan Kesadaran}

Masyarakat akan Kesehatan

Strategi dalam mengoptimalkan pemanfaatan fosfor pada anak usia dini sangat dipengaruhi oleh kesadaran masyarakat akan pentingnya hidup sehat yang termasuk kesehatan tubuh dan kesehatan lingkungan (Ismaniar, 2010). Hal tersebut dikarenakan kesehatan tubuh dan kesehatan lingkungan merupakan dua unsur yang saling mempengaruhi dalam proses pertumbuhan anak usia dini.

Upaya dalam meningkatkan kesadaran masyarakat akan hidup sehat mengalami banyak kendala, karena kurang tersedianya air bersih, fasilitas sanitasi kurang tersedia, mencemarkan udara dalam 
skala mikro maupun makro. Permasalahan tersebut menjadi kendala dalam meningkatkan kehidupan sehat bagi anak usia dini, karena gizi yang diberikan untuk anak usia dini, jika tidak terdapat dukungan yang baik dari lingkungan akan menghambat optimalisasi pembentukan kesehatan fisik.

Strategi yang dapat dilakukan dalam membentuk kesadaran masyarakat untuk hidup sehat, terutama anak usia dini yaitu dengan tiga cara, meliputi: 1) optimalisasi pendidikan jasmani, olahraga dan rekreasi di setiap pendidikan formal, informal maupun non formal, 2) kampanye yang masif dari kementerian kesehatan Republik Indonesia untuk mengajak masyarakat hidup sehat, dan 3) penguatan peran posyandu di setiap daerah dengan adanya pendampingan kepada masyarakat.

Optimalisasi peran pendidikan jasmani, olahraga dan rekreasi di setiap jenis pendidikan tentu melalui pendekatan yang berbeda. Pada pendidikan formal harus diajarkan kepada siswa untuk senantiasa menjaga kesehatan fisik maupun kesehatan lingkungan, menanamkan pengetahuan tersebut sangat penting untuk menciptakan budaya hidup sehat. Pada pendidikan non formal dilakukan dengan adanya berbagai pelatihan di setiap daerah, agar masyarakat mengetahui pentingnya hidup sehat, terutama kesehatan fisik untuk anak usia dini. Pada pendidikan informal penting untuk memberikan edukasi kepada keluarga terutama yang memiliki anak usia dini mengenai pentingnya hidup sehat dalam proses pertumbuhan fisik anak usia dini.

Kampanye yang masif perlu untuk dilakukan oleh kementerian kesehatan Republik Indonesia, karena sangat berpengaruh terhadap pembentukan persepsi masyarakat. Selama ini kampanye yang dilakukan masih pada tataran pentingnya kalsium bagi pertumbuhan tulang dan gigi, padahal unsur fosfor sangat berpengaruh dalam pembentukan tulang dan gigi. Hal ini menandakan bahwa kampanye yang dilakukan oleh Kementerian Kesehatan Republik Indonesia tidak bisa hanya terfokus pada pentingnya kalsium pada tubuh, akan tetapi menambahkan unsur fosfor dalam pembentukan kesehatan fisik anak usia dini.

Penguatan peran posyandu merupakan aspek yang paling dekat dengan kehidupan masyarakat, karena posyandu merupakan lembaga yang menangani kesehatan masyarakat, terutama untuk anak usia dini. Dalam kegiatannya posyandu perlu memberikan informasi kepada keluarga akan pentingnya fosfor dalam membentuk fisik anak usia dini, terutama manfaat dalam pembentukan sel otak yang menjadi unsur penting dalam membentuk 
kecerdasan anak. Pemberian edukasi yang dilakukan oleh posyandu akan menjadi sumber informasi primer dalam membentuk kesadaran hidup sehat bagi masyarakat.

C. Pelibatan pihak-pihak dalam Mengoptimalkan Pemanfaatan Fosfor bagi Anak Usia Dini

Upaya untuk optimalisasi pemanfaatan fosfor dalam pembentukan fisik anak usia dini perlu dengan adanya dukungan yang masif dari berbagai pihak, karena permasalahan yang terjadi di masyarakat tidak bisa diselesaikan dengan mengandalkan satu pihak.

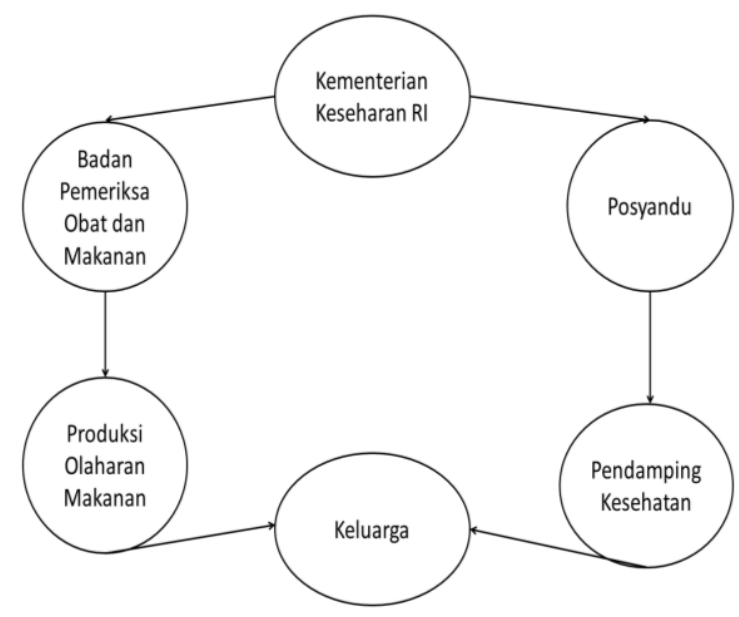

Gambar 1. Pihak-Pihak yang Terlibat dalam Membangun Kesadaran Hidup Sehat

Gambar tersebut menjelaskan bahwa peran yang sangat strategis dimiliki oleh Kementerian Kesehatan RI sebagai pemegang kebijakan mengenai kesehatan masyarakat, dalam pelaksanaannya Kementerian Kesehatan RI perlu melakukan kerja sama dengan Badan
Pemeriksa Obat dan Makanan (BPOM) dalam mengawasi maupun mengecek makanan-makanan yang memiliki kadar fosfor, sehingga peredarannya dapat dikontrol. Hal ini menjadi sangat penting dalam mengoptimalkan pemanfaatan fosfor bagi kesehatan fisik anak usia ini.

Pada tataran lain perlu adanya kolaborasi dengan posyandu yang memberikan edukasi kepada keluarga mengenai pentingnya fosfor dalam pertumbuhan fisik anak usia ini. Dalam mengoptimalkan posyandu perlu adanya pendampingan yang dilakukan kepada setiap keluarga yang memiliki anak usia dini, sehingga posyandu akan proaktif dalam membina kesehatan fisik anak usia dini.

Semua pihak tersebut harus saling bersinergi satu dengan yang lainnya dalam mengoptimalkan mengonsumsi fosfor dalam tubuh anak usia dini, sehingga terdapat kesadaran dari masyarakat akan pentingnya membentuk generasi yang sehat, cerdas dan mempunyai fisik kuat dalam menjalani kehidupan sehari-hari.

\section{KESIMPULAN}

Mineral fosfor sangat berperan penting dalam membentuk kesehatan fisik anak usia dini, karena bermanfaat untuk pertumbuhan tulang, gigi maupun 
pembentukan sel-sel otak yang berfungsi untuk meningkatkan kecerdasan. Optimalisasi pemanfaatan fosfor bagi anak usia dini perlu dengan adanya dukungan yang masif dari pemerintah, pendidikan maupun masyarakat yang senantiasa membudayakan hidup sehat. Rekomendasi untuk penelitian selanjutnya, yaitu perlu untuk mengkaji intensitas konsumsi makanan yang mengandung fosfor di setiap wilayah di Indonesia, sehingga akan ditemukan data mengenai pemanfaatan fosfor untuk anak usia dini dan diketahui keseimbangan gizi anak Indonesia.

\section{DAFTAR PUSTAKA}

Ani, L. S. (2011). Metabolisme Zat Besi Pada Tubuh Manusia. Widya Biologi, 2(1), 1-76.

Ariati, N., \& Ratnayani, K. (2017). Skrining potensi jenis biji polongpolongan (Famili Fabaceae) dan biji labu-labuan (Famili Cucurbitaceae) sebagai koagulan alami. Jurnal Kimia, 11(1), 15-22.

Cardoso, F. L., Brites, D., \& Brito, M. A. (2010). Looking at the blood-brain barrier: Molecular anatomy and possible investigation approaches. Brain Research Reviews. https://doi.org/10.1016/j.brainresrev.2 010.05 .003

Cupisti, A., \& Kalantar-Zadeh, K. (2013). Management of Natural and Added Dietary Phosphorus Burden in Kidney Disease. Seminars in Nephrology, 33(2), 180-190. https://doi.org/10.1016/j.semnephrol.2 012.12 .018

de Tavernier, J. (2012). Food Citizenship: Is There a Duty for Responsible
Consumption? Journal of Agricultural and Environmental Ethics, 25(6), 895907. https://doi.org/10.1007/s10806011-9366-7

Emilia, E. (2009). Pendidikan Gizi Sebagai Salah Satu Sarana Perubahan Perilaku Gizi Pada Remaja. Jurnal Tabularasa Pps Unimed, 6(2), 161-174.

Gunardi, H., Kartasasmita, C. B., Hadinegoro, S. R. S., Satari, H. I., Oswari, H., Pusponegoro, H. D., ... Hendrarto, T. W. (2017). Jadwal Imunisasi Anak Usia $0-18$ tahun Rekomendasi Ikatan Dokter Anak Indonesia 2017. Sari Pediatri, 18(5), 417-422.

Hill, W. R., \& Fanta, S. E. (2008). Phosphorus and light colimit periphyton growth at subsaturating irradiances. Freshwater Biology, 53(2), 215-225. https://doi.org/10.1111/j.13652427.2007.01885.x

Ismaniar. (2010). Metode- Metode Pengembangan Perilaku Hidup Sehat Anak Usia Dini. PEDAGOGI | Jurnal Ilmiah Ilmu Pendidikan, X(2), 100108.

Jewitt, C. (2013). Multimodal methods for researching digital technologies. In The SAGE Handbook of Digital Technology Research (pp. 250-265). https://doi.org/10.4135/978144628222 9.n18

Komariyah, L. (2011). Fungsi Makanan Bagi Tubuh Manusia. In Jurnal Pendidikan Olahraga (pp. 1-10).

Kuniano, D. (2015). Menjaga Kesehatan di Usia Lanjut. Jurnal Olahraga Prestasi, 11(2), 19-30.

Kusbiantoro, D. (2015). PERTUMBUHAN DAN PERKEMBANGAN ANAK USIA PRASEKOLAH DI TAMAN KANAK-KANAK ABA 1 LAMONGAN. Surya, 7(1), 1-8.

Lee, J. B., \& Sung, J. H. (2013). Organ-ona-chip technology and microfluidic whole-body models for pharmacokinetic drug toxicity 
screening. Biotechnology Journal. https://doi.org/10.1002/biot.20130008 6

López-Arredondo, D. L., Leyva-González, M. A., González-Morales, S. I., López-Bucio, J., \& Herrera-Estrella, L. (2014). Phosphate Nutrition: Improving Low-Phosphate Tolerance in Crops. Annual Review of Plant Biology, 65(1), 95-123. https://doi.org/10.1146/annurevarplant-050213-035949

Ma, Y., Samaraweera, M., Cooke-Hubley, S., Kirby, B. J., Karaplis, A. C., Lanske, B., \& Kovacs, C. S. (2014). Neither absence nor excess of FGF23 disturbs murine fetal-placental phosphorus homeostasis or prenatal skeletal development and mineralization. Endocrinology, 155(5), 1596-1605.

https://doi.org/10.1210/en.2013-2061

Mardiani, A., Sumarmono, J., \& Setyawardani, T. (2013). Total Bakteri Asam Laktat, Kadar Air, dan Protein Keju Peram Susu Kambing yang Mengandung Probiotik Lactobacillus casei dan Bifidobacterium longum. Jurnal Ilmiah Peternakan, 1(1), 244253.

Moniaga, V., \& Pangemanan, D. H. C. (2013). Pengaruh senam bugar lansia terhadap tekanan darah penderita hipertensi di bplu senja cerah paniki bawah 2. Jurnal E-Biomedik (eBM), 1(2), 785-789.

Musfiroh, I., Susanti, N. N., \& Sukmawardani, Y. (2016). Analisis Kalium dan Kalsium pada Ikan Kembung dan Ikan Gabus. Ijpst, 3(1), 26-30.

Nasution, S. B. (2016). Analisa Kadar Besi (Fe) Pada Bayam Hijau Sesudah Perebusan Dengan Masa Simpan 1 Jam 3 Jam dan 5 Jam. Jurnal Ilmiah Pannmed2, 11(1), 1-3.

Rahayu, D., \& K.S. Sugiarto, D. (2015). Penentuan Kadar Mineral Seng (Zn) dan Fosfor (P) dalam Nugget Ikan
Gabus (Channa striata) - Rumput Laut Merah (Eucheuma spinosum). Sains Dan Seni ITS, 4(2), 2337-3520.

Rosmiati, A. (2014). Teknik Stimulasi dalam Pendidikan Karakter Anak Usia Dini melalui Lirik Lagu Dolanan. Resital: Jurnal Seni Pertunjukan, 15(1), 71-82.

Satish Kumar, R., Kanmani, P., Yuvaraj, N., Paari, K. A., Pattukumar, V., \& Arul, V. (2013). Traditional Indian fermented foods: A rich source of lactic acid bacteria. International Journal of Food Sciences and Nutrition.

https://doi.org/10.3109/09637486.2012 .746288

Siswanto; Budisetyawati. (2013). Peran Beberapa Zat Gizi Mikro Dalam Sistem Imunitas. Gizi Indon, 36(1), 57-64.

Suarni, \& Muh. Yasin. (2016). Jagung sebagai Sumber Pangan Fungsional. Pangan Dan Pertanian, 5(6), 1-16.

Syarifah, A. (2015). Syarifah Am inah et. al.: Kandungan Nut risi dan Sifat Fungsional Tanam an Kelor ( $\mathrm{M}$ oringa oleifera ). Buletin Pertanian Perkotaan, 5(30), 35-44.

Widayatun, \& Fatoni, Z. (2013). Permasalahan Kesehatan dalam Kondisi Bencana:Peran Petugas Kesehatan dan Partisipasi Masyarakat (Health Problems in a Disaster Situation: the Role of Health Personnels and Community Participation). Jurnal Kependudukan Indonesia, 8(1), 37-52.

Yuan, Z., Pratt, S., \& Batstone, D. J. (2012). Phosphorus recovery from wastewater through microbial processes. Current Opinion in Biotechnology. https://doi.org/10.1016/j.copbio.2012.0 8.001

Zhao, M., Niu, X., Guan, L., Qian, H., Wang, W., Sha, J., \& Wang, Y. (2016). Understanding the growth of black phosphorus crystals. 
Gladi Jurnal Ilmu Keolahragaan, 09 (1), Maret 2018 - 35

Sandey Tantra Paramitha

CrystEngComm, 18(40), 7737-7744.

https://doi.org/10.1039/C6CE01608A 
Gladi Jurnal Ilmu Keolahragaan, 09 (1), Maret 2018 - 36

Sandey Tantra Paramitha

Copyright (C) 2018, Gladi Jurnal Ilmu Keolahragaan, ISSN 1693-1556 (print), ISSN 2597-8942 (online) 